\title{
Risk for metabolic syndrome in a group of overweight children from South-East Romania
}

\section{Riscul de dezvoltare a sindromului metabolic la un grup de copii cu exces ponderal din sud-estul României}

\author{
Bianca I. Chesaru ${ }^{1}$, Michaela Dobre $^{2 *}$, Gabriel Murariu ${ }^{3}$, Aurel Nechita $^{4}$ \\ 1. "Dunarea de Jos" University of Galati, Faculty of Medicine and Pharmacy, Department of \\ Pharmaceutical Sciences \\ 2. "Dunarea de Jos" University of Galati, Faculty of Medicine and Pharmacy, Department of \\ Functional Sciences \\ 3. "Dunarea de Jos" University of Galati, Faculty of Sciences and Environment, Department of \\ Chemistry, Physics and Environment \\ 4. "Dunarea de Jos" University of, Galati, Faculty of Medicine and Pharmacy, Clinical Department
}

\begin{abstract}
The present study aims to identify and analyse the cardiometabolic risk factors associated with the metabolic syndrome in overweight children and adolescents. The study group included 163 overweight children and adolescents, average age: $13.02 \pm 3.42$ years. The following evaluations were performed: anthropometrical measurements, blood pressure measurements, biochemical tests investigating the lipid and carbohydrate metabolism. Metabolic syndrome was identified in 48 subjects (29.4\%). The risk to develop MS was found to be higher in males and within the 13-18 age group. The most common cardiometabolic risk factors were abdominal obesity (75.5\%) and high blood pressure (41.1\%), followed by low HDL-cholesterol (35\%), increased fasting blood glucose (23.3\%) and hypertriglyceridemia (17.8\%.). The variables under analysis exhibited significant correlations with the number of metabolic syndrome diagnosis criteria. The metabolic syndrome prevalence in the paediatric population affected by excess body weight has reached high values in our geographical area. It is thus justified to initiate screening activities for the early detection and adequate treatment of the modifiable cardiometabolic risk factors, contributing to the prevention of long-term complications.
\end{abstract}

Keywords: overweight children, hypertension, dyslipidemia, metabolic syndrome

\section{Rezumat}

Studiul de față şi-a propus identificarea şi analizarea componentelor cu risc cardiometabolic asociate cu sindromul metabolic la copiii şi adolescenții cu exces ponderal. Lotul de studiu a inclus un număr de 163 de copii şi adolescenți cu exces ponderal, cu media de vârstă $13.02 \pm 3.42$ ani. S-au efectuat: măsurători antropo-

"Corresponding author: Michaela Dobre, "Dunarea de Jos" University of Galati, Faculty of Medicine and Pharmacy, Department of Functional Sciences, 35 Al. I. Cuza St.,800010 Galati, Romania, Tel/Fax: +40 236412100 , mobile: +40727 707 285, E-mail: mdobre@ugal.ro 
metrice, măsurarea tensiunii arteriale şi determinări biochimice pentru investigarea metabolismului lipidic şi glucidic. Prezența sindromului metabolic a fost înregistrată la 48 de subiecți (29.4\%). Riscul de a dezvolta SM a fost mai crescut la copiii de sex masculin şi la cei din grupa de vârstă 13-18 ani. Cele mai frecvente componente cu risc cardiometabolic au fost obezitatea abdominală (75.5\%) şi hipertensiunea arterială (41.1\%), urmate de HDL-colesterol scăzut 35\%, glicemie à jeun crescută (23.3\%) şi hipertrigliceridemie (17.8\%). Variabilele analizate au prezentat corelații semnificative cu numărul de criterii de diagnostic ale sindromului metabolic. Prevalența sindromului metabolic în populația pediatrică cu exces ponderal este crescută în zona noastră geografică. Se justifică astfel inițierea activităților de screening pentru depistarea precoce şi intervenția adecvată asupra factorilor de risc cardiometabolici modificabili, contribuind în acest mod la prevenirea complicațiilor acestora pe termen lung.

Cuvinte cheie: obezitate abdominală, copii, hipertensiune arterială, dislipidemie, sindrom metabolic

Received: 13 ${ }^{\text {th }}$ November 2012; Accepted: $28^{\text {th }}$ February 2013; Published: $14^{\text {th }}$ March 2013.

\section{Introduction}

The constellation of anthropometric, functional and biochemical consequences of overnutrition may be summarised under the name of metabolic syndrome (MS), characterised by abdominal adipose excess, associated two or more cardiometabolic risk factors: high blood pressure, atherogenic dyslipidaemia (hypertriglyceridemia, low HDL-cholesterol) and disorders of the glucose metabolism (fasting hyperglycaemia, impaired glucose tolerance or type 2 diabetes mellitus). MS was intensely studied on adults, but research was directed towards the paediatric population only in the context of an extremely worrying ascending trend of obesity in children and adolescents. According to a study from 2004 conducted in 79 countries, the World Health Organization (WHO) considers that there are 250 million obese people in the world, out of whom 22 million are estimated to be children under 5, thus evincing the idea that $50 \%$ of these children are to become obese adults (1). Studies in Romania estimated that $24.5 \%$ of children aged $7-11$ were overweight (2). Childhood obesity may be responsible for the early onset of systemic arterial hypertension, insulin resistance and dyslipidaemia in adolescence and increased risk of developing type 2 diabetes mellitus, metabolic syndrome and cardiovascular diseases in adulthood (3-5). Although no standardised and unanimously accepted definition of the MS for the paediatric age exists, the presence of the cardiometabolic risk factors at an early age with consequences in adulthood has given an increased impetus to research in this direction for children and adolescents $(6,7)$. Data on the prevalence of MS in the paediatric population of Romania is extremely scarce, prompting the present study as an attempt to provide better documentation on this topic.

\section{Materials and methods}

The study was a clinical and statistical analysis based on observational data, which prospectively assessed a lot of 163 children and adolescents with excess body weight ( 84 boys and 79 girls, $\mathrm{M} / \mathrm{F}$ ratio $=1.06$ ), who were successively admitted to the "Sf. Ioan" Clinical Emergency Children's Hospital in Galați for recurring health problems. The subjects were accepted into the study after the written informed consent was signed by their parents or legal guardians. The informed consent for participation in the study was assessed and advised by the Ethical Commission of "Dunărea de Jos" University of Galați.

The weight excess (obesity and overweight) was diagnosed on the basis of the medical history, the complete clinical exam (somatic aspect, distribution of the adipose tissue) and anthropometric measurements - height, weight, body mass index (BMI) - in relation to age and gender according to the Centers for Disease Control and Prevention (CDC) criteria (8). Thus, obesity was established according to the criterion: 
$\mathrm{BMI} \geq$ the 95 th percentile for age and gender, and overweight according to the criterion: BMI between 85th and 95th percentile for age and gender. The study did not include subjects with a history of secondary obesity (caused by endocrine, genetic, neurological disorders, with a suggestive clinical exam confirmed by specialists), a history of diabetes or primary hyperlipidaemia, pharmacological treatment that might have influenced their metabolic profile or blood pressure.

In order to better define MS, we used the criteria for children and adolescents proposed by the International Diabetes Federation (IDF) in 2007 and adapted according to the 2009 consensus amendments for adults, and relates blood pressure to percentile values as described by Weiss et al. and Ferreira et al. (6-10). Therefore, MS was defined by the presence of at least three of the following criteria: waist circumference (WC) $\geq$ the 90th percentile for age and gender; blood pressure $(\mathrm{BP}) \geq$ the 95 th percentile for age, gender and height; triglycerides (TGL) $\geq$ $150 \mathrm{mg} / \mathrm{dL} ;$ HDL-cholesterol (HDLc) $<40$ $\mathrm{mg} / \mathrm{dL}$ (excepting girls aged 13-18, for whom the cut-off value was $50 \mathrm{mg} / \mathrm{dL}$ ), fasting blood glucose $(\mathrm{FBG}) \geq 100 \mathrm{mg} / \mathrm{dL}(5.6 \mathrm{mmol} / \mathrm{L})$.

\section{Anthropometric measurements}

The measurement of the weight was performed with a standard beam balance scale in the morning, before breakfast, with the patient in the upright position, barefoot and wearing light clothes. The height was measured on a standard height board; the patient was in an upright position, his/her heels, nates and occipital bone aligned on a vertical plane, without stretching the neck, and the lower eye socket rim in horizontal line with the external auditory conduct. BMI was calculated by dividing the mass $(\mathrm{kg})$ to the square of the height $\left(\mathrm{m}^{2}\right)$, and the data obtained were converted into the percentile corresponding to the age and gender by means of the 2000 CDC standard monograms (11). The waist circumference (WC) was measured with the patient in upright position, the legs slightly apart and relaxed abdomen at the end of a complete expiration, in mid-distance between the upper iliac crest and the costal rim, at the level of the navel, on the median axillary line, by means of the waist meter. WC values percentiles corresponding to the age and gender were interpreted as shown in a previous study (12). The WC was chosen as a specific measurement as it is correlated with the intra-abdominal adipose tissue mass, thus assessing central (abdominal) obesity.

\section{Blood pressure measurement}

The blood pressure was measured with the patient in a sitting position, after a rest of at least 5 minutes, by means of a sphygmomanometer with an appropriate size cuff, placed at the level of the right arm held in the pre-cordial area (the auscultatory method). Three measurements were made, recording the average values of the systolic blood pressure (SBP) and diastolic blood pressure (DBP). When the blood pressure was over the $95^{\text {th }}$ percentile for the first measurement, this were repeated in two different days. The measurement of blood pressure values and the subjects' classification followed the recommendations of the American Academy of Pediatrics (AAP) by relation to the corresponding percentiles for age, gender and height (13).

\section{Laboratory tests}

These tests were performed by enzymatic methods, using appropriate kits for Vitros 950 analyser (Ortho Clinical Diagnostics, Johnson \& Johnson, USA) at the hospital Clinical Laboratory. The venous blood samples were drawn according to the standard laboratory procedures. No haemolysed, lactescent or icteric serums were used. The tests included the determination of the following parameters: total cholesterol (tC), HDLc, TGL and FBG test. The LDL-cholesterol value (LDLc) was calculated by means of the Friedewald formula. To assess the lipid profile, the ratios TGL/HDLc and tC/HDLc were calculated, and the values over 3 and 4 , respectively were considerred signs of atherogenesis. The interpretation of serum lipids and lipoproteins values in children and adolescents followed the National Cholesterol Education Program 

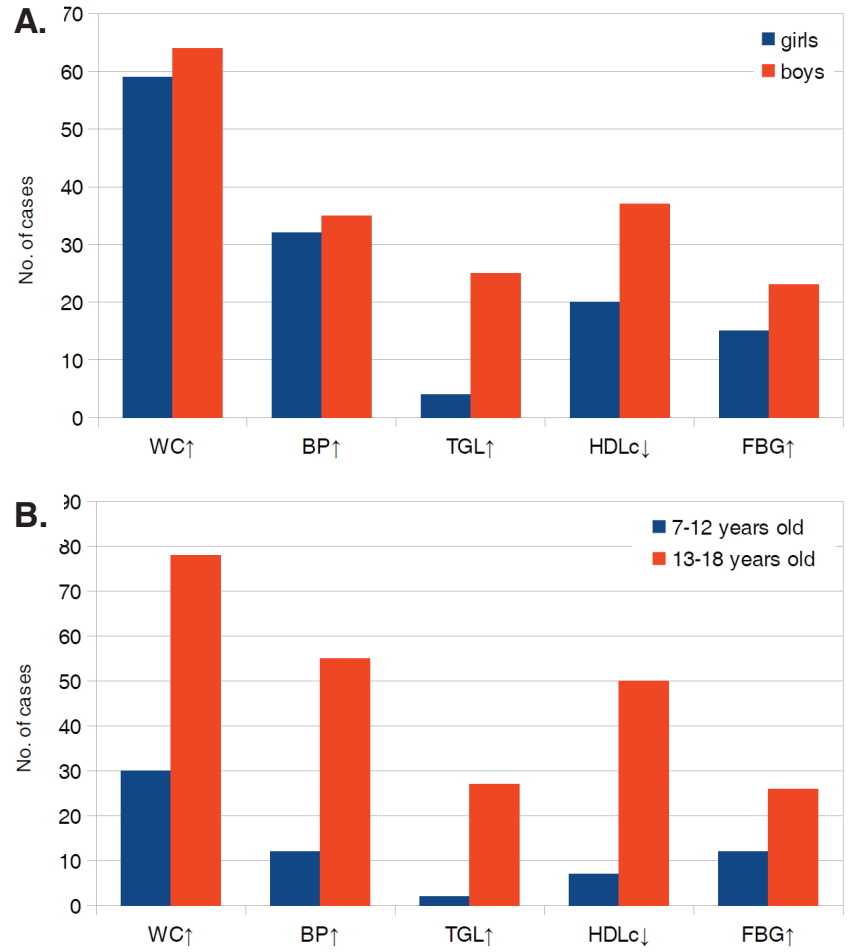

Figure 1. Distribution of metabolic syndrome criteria occurence by gender (A) and by age (B)

(NCEP) recommendations, while for fasting blood glucose, the recommendations of the American Diabetes Association (ADA) $(14,15)$.

\section{Statistical analysis and processing}

The data were statistically analysed by means of the Statistica 7 software. Continuous numerical values were expressed as means \pm standard deviation (SD), while category variables were listed as frequencies. In order to emphasize the potential differences between the subgroups generated within the experimental lot by sex and age, the t-student parametric test or Mann-Whitney Rank Sum Test were used, and frequency comparisons among subgroups made use of the $\chi^{2}$ test. The statistical significance threshold alpha 0.05 was selected, corresponding to a confidence level of $95 \%$. The assessment of the correlations between the variables under analysis was performed by means of the Pearson correlation coefficient.

\section{Results}

Out of the total of 163 subjects included in the study, 61 (37.4\%) exhibited one MS diagnosis criterion, 45 (27.6\%) associated two MS diagnosis criteria, 34 (20.9\%) combined three criteria, 12 (7.4\%) combined four criteria, and only $2(1.2 \%)$ showed all the five criteria. The absence of any MS diagnosis criterion out of the five was seen in 9 (5.5\%) subjects. The most common association between two components was obesity and/or abdominal obesity and high blood pressure, found in 21/45 subjects (46.6\%) subjects. When considering the association of three criteria, obesity and/or abdominal obesity, high blood pressure and low HDLc were found in 13/48 (27\%) MS subjects. The presence of MS, defined as the association of minimum 3 out of 5 criteria, was $29.4 \%$, with no statistically significant difference in the 1318 age group (34.8\%) as compared to the 7-12 age group $(20 \%)(\mathrm{p}=0.088)$. The statistical analysis showed no significant differences in the prevalence MS according to gender.

The most common two MS indicators in the total group were abdominal obesity ( $\mathrm{WC} \geq$ the 90th percentile) in $123(75.5 \%)$ of the cases, and high blood pressure (BP $\geq$ the 95th percentile) in $67(41.1 \%)$ of the cases (Figure 1).

All subjects included in the study showed excess body weight $(\mathrm{BMI} \geq$ the 85 th percentile). Out of these subjects, 32/163 (19.6\%) were overweight and 131/163 (80.4\%) obese, without any significant gender differences. Abdominal obesity, assessed by the WC value, was identified in $75.5 \%$ of the subjects: $88.5 \%(116 / 131)$ of the obese individuals and $21.9 \%$ (7/32) of the overweight ones, with no significant gender differences. A statistically significant difference was observed between age groups, pointing to an increased frequency of WC in the 13 to 18 years old paediatric population $(\mathrm{P}<0.001)$. The same age group had a significant increase in cases of hypertension 
Table 1 Study lot descriptive statistics for clinical and metabolic parameters

\begin{tabular}{lcc}
\hline & Mean & Std.Dev. \\
\hline Age (years) & 13.02 & 3.42 \\
Height $(\mathrm{m})$ & 1.58 & 0.15 \\
Weight $(\mathrm{kg})$ & 70.09 & 20.60 \\
BMI $\left(\mathrm{Kg} / \mathrm{m}^{2}\right)$ & 27.44 & 4.03 \\
WC $(\mathrm{cm})$ & 90.62 & 11.19 \\
$\mathrm{SBP}^{*}(\mathrm{mmHg})$ & 124.00 & 15.50 \\
$\mathrm{DBP}^{* *}(\mathrm{mmHg})$ & 75.99 & 7.73 \\
tC $(\mathrm{mg} / \mathrm{dL})$ & 166.08 & 29.96 \\
$\mathrm{LDLc}(\mathrm{mg} / \mathrm{dL})$ & 97.85 & 27.77 \\
$\mathrm{HDLc}(\mathrm{mg} / \mathrm{dL})$ & 46.29 & 12.65 \\
VLDLc $(\mathrm{mg} / \mathrm{dL})$ & 22.02 & 10.30 \\
TGL $(\mathrm{mg} / \mathrm{dL})$ & 109.90 & 50.66 \\
TGL/HDLc & 2.70 & 1.80 \\
tC/HDLc & 3.84 & 1.41 \\
FBG $(\mathrm{mg} / \mathrm{dL})$ & 90.53 & 16.37 \\
\hline
\end{tabular}

( $\mathrm{P}<0.001)$. Hypertensive status was not associated with any gender in particular.

The study of blood pressure revealed a prevalence of hypertension (HT) of $41.1 \%$ and pre-hypertension of $14.1 \%$.

The evaluation of the lipid profile led to the following results in decreasing order: prevalence of low HDLc in 35\%, hypertriglyceridemia in $17.8 \%$, hypercholesterolemia in $11 \%$ and high LDLc in $10.4 \%$. Male subjects and those aged 13 to 18 showed some modified values of all lipid parameters, without achieving statistical significance: $P=0.264$ (for tryglicerides), $\mathrm{P}=0.143$ (for HDLc). Hypertriglyceridemia and reduced concentrations of HDLc, especially when are associated, arise from changes in eating habits that lead to obesity and induce susceptibility to MS, with the exception of specific genetic influences. Since 27 subjects combined two of the modifications mentioned above, the prevalence of dyslipidemia was
$16.6 \%$. High values of the ratios TGL/HDLc and $\mathrm{tC} / \mathrm{HDLc}$ were registered in $31.3 \%$ and $39.3 \%$ of the subjects, respectively.

Fasting hyperglycemia was seen in $23.3 \%$ of the subjects, at slightly higher levels in boys and the 13-18 years of age group, without achieving statistical significance $(\mathrm{P}=0.127)$. No patient was diagnosed with type 2 diabetes mellitus.

Table 1 lists the descriptive statistic of clinical and metabolic parameters under investigation, and Table 2, the overall correlations between parameters.

In summary, significant positive correlations were established between the majority of analysed variables and MS diagnosis criteria, with the exception of HDLc, which has a negative correlation. The anthropometric parameters (height, weight, BMI and WC) showed significant positive correlations with most of the variables under analysis, non significant positive correlations with the FBG and negative correlations with HDLc. SBP showed significant positive correlations with the anthropometric parameters analysed, and some of the indices of the lipid profile. The correlations of SBP to HDLc were negative, but not statistically significant. The parameters investigating the lipid metabolism showed significant positive correlations, as follows: $\mathrm{tC}$ and LDLc with the anthropometric indices, VLDLc and the ratio tC/HDLc with the anthropometric indices, SBP and TGL, TGL and the ratio TGL/HDLc with the anthropometric indices, SBP and DBP. HDLc showed negative correlations with all the variables under analysis, but non significant. FBG was positively correlated only with the number of MS diagnosis criteria.

\section{Discussions}

The research results indicated an important prevalence of cardiovascular and metabolic risk factors in the investigated paediatric population, despite the subjects' young age. In total, 154 subjects were found to present at least 
one risk factor $(94.5 \%)$ and more than a quarter of the study group had accumulated at least three MS diagnosis criteria. MS prevalence in the overweight patients included in this study was elevated, and the 13-18 age group was the most affected (34.8\%, i.e. 1 of 3 adolescents). Although the prevalence of MS in ages 7-12 is lower ( 1 of 5 subjects), it should not be neglected, as it signals a lower age limit for the onset of the metabolic consequences of excess weight. Our results are comparable to some documented values, but the studies on this topic reveal a high variability of the MS prevalence, accounted for by the differences in the demographic characteristics of the populations under study and, in the same time, the different definitions used in diagnosing MS $(16,17)$. The childhood MS onset trends are difficult to quantify and compare on larger scale mainly because there is no universally accepted definition of paediatric MS, thus making MS diagnosis very difficult to establish in young age. Difficulties arise mostly from the incomplete picture of MS components seen in paediatric population. Moreover, unlike in adults, childhood MS components and their pathophysiological mechanisms are influenced by growth and puberty, not only by gender, ethnicity and race (18-21). The assessment of risk factors defining MS is more difficult in the paediatric population in our geographical area due to the lack of statistics and specific benchmarks. Based on the study results, MS risk factors were ranked according to their occurrence in the study lot: most frequent $(75.5 \%)$ was abdominal obesity, followed in descending order by hypertension (41.1\%), hypo-HDL-cholesterol (35\%), fasting hyperglycaemia $(23.3 \%)$ and hypertriglyceridemia (17.8\%). The results of this study point to the fact that cardiovascular and MS risk factors originate in childhood and are closely related to obesity.

Abdominal obesity, appreciated by the value of the $\mathrm{WC} \geq$ the 90th percentile for age and gender, was the most reliable component in classifying subjects as having MS. The existing correlation between the anthropometric indices and the number of MS diagnosis criteria led us to the conclusion that a more severe MS condition is to be found in subjects with a high degree of obesity and/or abdominal obesity. Thus it can be inferred that fat excess and especially abdominal (central) fat excess in children and adolescents is associated with multiple cardiometabolic risk factors, the association of which increases the severity of MS, as is has already been shown for adults (22).

It still remains to be investigated why just some obese individuals develop MS. It is usually attributed to insulin resistance, which is the physiopathological factor incriminated in the occurrence of this syndrome (23).

Presently, WC measuring is not routinely done for children, mostly because there are no WC cut-off values established for paediatric population. The main predictor of cardiometabolic risks associated to obesity in study subjects was BMI, although certain studies showed that WC tops BMI in its association to insulin resistance, metabolic syndrome and cardiovascular disease in children, and therefore may be included in practice as the simplest instrument to identify MS-prone children $(24,25)$.

In our study, it was found that blood pressure increases in a proportional manner with BMI and WC, and it correlates better with WC. All these findings support the role of obesity as a risk factor for arterial hypertension, and the use of the BMI-WC combination as compared to using one of the parameters may increase the predictive value of developing arterial hypertension and MS.

The prevalence and diagnosis rate of hypertension in children and adolescents appear to be on the rise, partly as a consequence of more frequent occurrences of body weight excess at an early age (26). The obesity that develops in childhood increases the risk of associated diseases, as well as the risk of persisting into adulthood, when cardiometabolic complications are more likely to occur $(3,5)$. In the present study, the presence of hypertension 


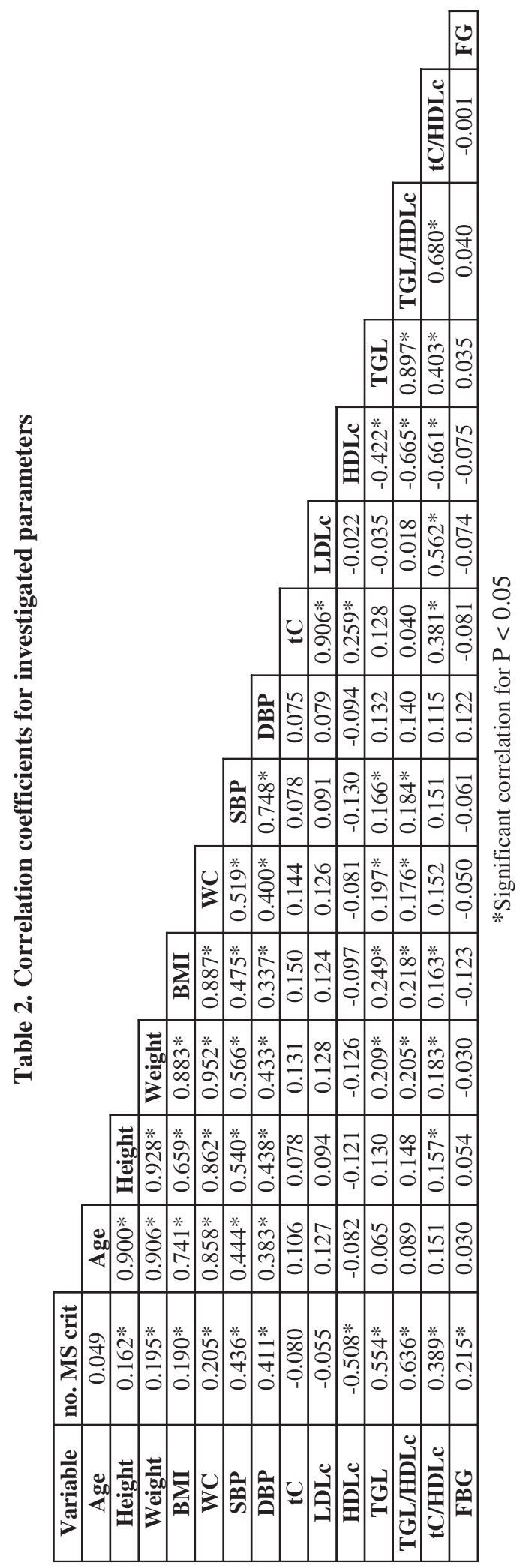


ranked second in frequency among the MS diagnosis criteria used. The prevalence of hypertension $(41.1 \%)$ and pre-hypertension (14.1\%) estimated in our study are in accordance the reports on paediatric subjects with excessive body weight in Canada (19.5\%), several European countries $(21,8 \%)$ and the USA $(49 \%)(4,27$, 28). Upon analysing our data, it can be said that SBP and DBP exhibit significant but weak correlations with some of the indices of the lipid metabolism (TGL and TGL/HDLc ratio). The blood pressure values are therefore not dependent on the presence the disorders of the lipid or glucose metabolism, but are best correlated with the degree of obesity. Therefore it may be inferred that the values of blood pressure can be lowered by losing weight.

The main lipid disorder found in our investigated MS subjects was the average HDLc value much below the lowest accepted level of $40 \mathrm{mg} / \mathrm{dL}$ and low HDLc levels is known to be linked to elevated cardiovascular risk. These results are confirmed by similar studies maintaining that atherosclerosis starts in childhood and progresses throughout life (29).

The reduced prevalence of hypertriglyceridemia $(17.8 \%)$ might imply that the critical value of TGL used in the IDF MS-defining criteria is too high in children, and the cut-off value of triglyceridemia associated to the increased MS risk has yet to be determined. An alternative to using IDF cut-offs would be to refer to normal percentile values for the patient's age and gender, which would ensure a more pertinent evaluation. This proposal relies on the fact that the lipid serum levels vary according to age and gender, as proven by other research (30). The explanation may be that the low prevalence of high LDLc belongs to the MS-specific type of dyslipidemia which includes hypertriglyceridemia, low HDLc while LDLc is not altered quantitatively, but qualitatively by the presence of small and dense LDL particles (31). The significant correlations of the indices of the lipid metabolism with the an- thropometric parameters, which the present study points to, are another argument in favour of the connection between dyslipidemia and the severity of excess weight.

In adults, the values of the lipoprotein ratios are acknowledged as more useful markers in estimating the atherogenetic and insulin resistant cardiovascular risk than isolated lipid values, as they reflect the interactions between lipid fractions (25). Conversely, in paediatric subjects the importance of these ratios is understudied from a clinical and prognostic point of view. In the present study, the correlations of the TGL/HDLc and tC/HDLc ratios with the number of MS criteria and the BP values were better when compared to individually analysed lipid fractions. These results, comparable to the limited data available in literature, allow us to conclude that their determination in paediatric subjects may be useful for the estimation of the cardiometabolic risk (32).

Similarly to other research focussing on this age, the present study showed no increased prevalence of high fasting blood glucose (23.3\%), but this should not be disregarded (16). The subjects classified as pre-diabetic at the moment, represent a category at increased risk of developing type 2 diabetes mellitus and MS, even more so if other risk factors are associated. This aspect is also stressed in our study, by the significant correlation between the values of fasting blood sugar levels and the severity of the MS. Two arguments may support these findings, namely the variety of disorders of glucose metabolism found in obese children, and the late development of this component in MS.

The high prevalence of cardiovascular and metabolic risk factors in the overweight pediatric population suggests that early screening for weight excess together with the timely implementation of lifestyle changes is essential for the prevention, control and management of obesity and its associated co-morbidities, such as the MS. Early age screening activities would imperatively call for a unanimously accepted 
definition of MS in children and adolescents. Early detection of weight excess and appropriate intervention upon reversible cardio-metabolic risk factors will ultimately help prevent long-term complications.

\section{Conclusions}

The MS prevalence in the paediatric population affected by excess body weight has reached high values in our geographical area, especially in the 13-18 years old group. The most common cardiometabolic risk factors revealed were abdominal obesity and high blood pressure, followed by low HDL-cholesterol, increased fasting blood glucose and hypertriglyceridemia.

\section{References}

1. Joliffe CJ, Janssen I. Development of age-specific metabolic syndrome criteria that are linked to the Adult Treatment Panel III and International Diabetes Federation Criteria. J Am Coll Cardiol, 2007; 49(8):891-898

2. Mocanu V, Galeşanu C, Mandasescu S, Haliga R, Costan AR, Badescu M. Depistarea si preventia obezitatii la copii - consideratii practice / Detection and prevention of obesity in children - practical considerations. Ro J Pediatr. 2011; LX(3):223-232.

3. Kipping RR, Jago R, Lawlor DA. Obesity in children. Part 1: epidemiology, measurement, risk factors, and screening. BMJ 2008; 337(a1824): 922-7

4. Salvadori M, Sontrop JM, Garg AX, Truong J, Suri RS, Mahmud FH et al. Elevated blood pressure in relation to overweight and obesity among children in a rural Canadian community. Pediatrics 2008; 122:e821-7.

5. Sun SS, Liang R, Huang TTK, Daniels SR, Arslanian $\mathrm{S}$, Liu K et al. Childhood obesity predicts adult metabolic syndrome: the Fels Longitudinal Study. J Pediatr 2008; 152(2):191-200.

6. Zimmet P, Alberti KGMM, Kaufman F, Tajima N, Silink M, Arslanian S. et al., IDF Consensus Group. The metabolic syndrome in children and adolescents - an IDF consensus report. Pediatric Diabetes 2007; 8(5): 299-306.

7. Alberti KGMM, Eckel RH, Grundy SM, Zimmet PZ, Cleeman JI, Donato KA et al., Harmonizing the metabolic syndrome: A Joint Interim Statement of the International Diabetes Federation Task Force on Epidemiology and Prevention; National Heart, Lung, and Blood Institute; American Heart Association; World Heart Federation; International Atherosclerosis Society; and International Association for the Study of Obesity. Circulation 2009; 120:1640-1645.
8. Kuczmarski RJ, Odgen CL, Grummer-Strawn LM, Flegal KM, Guo SS, Wei R et al., CDC growth charts: United States. Adv Data 2000; 314:1-28.

9. Weiss R, Dziura J, Burgert TS, Tamborlane WV, Taksali SE, Yeckel CW, et al., Obesity and the metabolic syndrome in children and adolescents. N Engl J Med 2004; 350:2362-2374.

10. Ferreira AP, Oliveira CER, França NM., Metabolic syndrome and risk factors for cardiovascular disease in obese children; the relationship with insulin resistance (HOMA-IR). J Pediatr 2007, 83(1):21-26.

11. CDC Growth Charts, Data Table of BMI-for-age Charts. 2000; Available via http://www.cdc.gov/growthcharts/html_charts/bmiagerev. htm Accessed 23 July 2012.

12. Fernández JR, Redden DT, Pietrobelli A, Allison DB. Waist Circumference Percentiles in Nationally Representative Samples of African-American, EuropeanAmerican, and Mexican-American Children and Adolescents. J.Pediatr 2004; 145(4):439-444.

13. National High Blood Pressure Education Program Working Group on High Blood Pressure in Children and Adolescents. The fourth report on the diagnosis, evaluation, and treatment of high blood pressure in children and adolescents. Pediatrics 2004;114(2):555-576.

14. NCEP Expert Panel of Blood Cholesterol levels in Children and Adolescents National Cholesterol Education Program (NCEP): Highlights of the Report of the Expert Panel of Blood Cholesterol levels in Children and Adolescents. Pediatrics 1992; 89(3):495-501.

15. American Diabetes Association (ADA). Diagnosis and classification of diabetes mellitus. Diabetes Care 2010; 33(suppl I):S62-S69.

16. Bokor S, Frelut ML, Vania A, Hadjiathanasiou CG, Anastasakou M, Malecka-Tendera E et al., Prevalence of metabolic syndrome in European obese children. Int $\mathrm{J}$ Pediatr Obes 2008; 3(2):3-8.

17. Reinehr T, de Sousa G, Toschke AM, Andler W. Comparison of metabolic syndrome prevalence using eight different definitions: a critical approach. Arch Dis Child 2007; 92(12):1067-1072.

18. Mancini MC. Metabolic syndrome in children and adolescents-criteria for diagnosis. Diabetol Metab Syndr. 2009; 1:20.

19. Saland JM. Update on the metabolic syndrome in children. Curr Opin Pediatr 2007; 19:2:183-191.

20. Huang TK, Ball GDC, Franks PW. Metabolic syndrome in youth: current issues and challenges. Appl Physiol Nutr Metab 2007; 32:1:13-22.

21. Goodman E. Pediatric metabolic syndrome: smoke and mirrors or true magic? J Pediatr. 2006; 148:149-151.

22. Lee S, Bacha F, Arslanian AS. Waist circumference, blood pressure, and lipid components on the metabolic syndrome. J Pediatr 2006; 149(6):809-816.

23. Pedrosa C, Oliveira B, Albuquerque I, SimoesPereira C, Vaz-de-Almeida M, Correia F. Obesity and 
metabolic syndrome in 7-9 years-old Portuguese schoolchildren. Diabetology \& Metabolic Syndrome 2010; 2(1):40.

24. Hirschler V, Maccallini G, Calcagno M, Aranda C, Jadzinsky M. Waist circumference identifies primary school children with metabolic syndrome abnormalities. Diabetes Technol Ther. 2007; 9(2):149-157.

25. Maffeis CM, Banzato C, Talamini G. Waist-height ratio, a useful index to identify high metabolic risk in overweight children. J Pediatr. 2008; 152(2):207-213.

26. Nitescu M., Furtunescu F.L., Otelea M, Rafila A, Streinu-Cercel A. Prevalence of metabolic syndrome parameters in a Romanian population of young adults. Revista Română de Medicină de Laborator. 2012; 20(3/4):207214.

27. Lobstein T, Jackson-Leach R. Estimated burden of paediatric obesity and comorbidities in Europe. Part 2. Numbers of children with indicators of obesity-related disease. Int J Pediatr Obes 2006; 1(1): 33-41.

28. Love-Osborne KA, Nadeau KJ, Sheeder J, Fenton LZ, Zeitler P. Presence of the metabolic syndrome in obese adolescents predicts impaired glucose tolerance and nonalcoholic fatty liver disease. J Adolesc Health. 2008; 42(6):543-8.
29. Morrison JA, Friedman LA, Gray-McGuire C. Metabolic syndrome in childhood predicts adult cardiovascular disease 25 years later: the Princeton Lipid Research Clinics Follow-up Study. Pediatrics 2007; 120(2):340-345.

30. Friedman LA, Morisson JA, Daniels SR, McCarthy WF, Sprecher DL. Sensitivity and specificity of pediatric lipid determinations for adult lipid status: findings from the Princeton Lipid Research Clinics-Prevalence Program Follow-up Study. Pediatrics 2006; 118(1):165-172.

31. Steinberger J, Daniels SR, Eckel RH, Hayman L, Lustig RH, McCridle B et al. Progress and challenges in metabolic syndrome in children and adolescents:a scientific statement from the American Heart Association atherosclerosis, Hypertension, and Obesity in the Young Committee of the Council on Cardiovascular Disease in the Young; Council on Cardiovascular Nursing; and Council on Nutrition, Physical activity, and Metabolism. Circulation 2009; 119(4):628-647.

32. Di Bonito P, Moio N, Scilla C, Cavuto L, Sibilio G, Sanguigno $\mathrm{E}$ et al., Usefulness of the High Triglyceride-to-HDL Cholesterol Ratio to Identify Cardiometabolic Risk Factors and Preclinical Signs of Organ Damage in Outpatient Children. Diabetes Care 2012; 35(1):158-62. 